DOI 10.15393/j10.art.2016.2701

Александр Владимирович Отливанчик

(Минск, Республика Беларусь)

AlexOt@yandex.ru

\title{
РЕДАКТОРСКИЕ ВСТАВКИ ДОСТОЕВСКОГО В СТАТЬЯХ, ОПУБЛИКОВАННЫХ В «ГРАЖДАНИНЕ» (1873-1874 гг.)
}

\begin{abstract}
Аннотация. Автор данной статьи атрибутирует Достоевскому текстовые вставки в «Петербургском обозрении» В. П. Мещерского («Гражданин». 1873. № 8), хронике «Из текущей жизни» («Гражданин». 1873. № 19), «Еженедельной хронике» («Гражданин». 1873. № 37), примечание к статье В. Ф. Пуцыковича «Хивинский поход» («Гражданин». 1873. № 24), редакторские ремарки в публикациях И. Ю. Некрасова, К. П. Победоносцева, В. Ф. Пуцыковича.

Ключевые слова: Ф. М. Достоевский, В. П. Мещерский, И. Ю. Некрасов, В. Ф. Пуцыкович, К. П. Победоносцев, еженедельник «Гражданин», атрибуция, редактирование
\end{abstract}

оставной частью работы Достоевского в «Гражданине» было написа-
ние различных редакторских текстов небольшого объема: вступительных и заключительных заметок к авторским публикациям, сносок-примечаний, текстовых вставок, редакционных объявлений и т. п. Корпус 21-го (посвященного «Гражданину») тома академического Полного собрания сочинений Достоевского включает примечания к 25 публикациям журнала, пять предисловных, пять послесловных заметок, восемь объявлений и сообщений. При активной работе Достоевского-редактора с авторскими рукописями (о которой шла речь в нашей предыдущей статье) редакторских микротекстов писателя в составе еженедельных выпусков «Гражданина» за январь 1873 - апрель 1874 года, несомненно, должно быть намного больше. Выявить большинство из них при дефиците документальных источников атрибуции невозможно. Наиболее сложна проблема «опознания» текстовых вставок в авторских статьях и неподписанных (без пометки Ред.) сносок-примечаний; в отдельных случаях сложно однозначно атрибутировать редакционные объявления журнала Ф. М. Достоевскому, В. П. Мещерскому (издателю) или В. Ф. Пуцыковичу (секретарю редакции). «Идеальным вариантом» для исследователя является в таких случаях недвусмысленное свидетельство автора публикации. Например, в случае с Н. Н. Страховым оно позволило выявить два заключительных абзаца 
Достоевского в его заметке «Нечто о Шиллере» (Время. 1861. № 2) [9, 261], короткую вставку Достоевского в его статье «Нечто о полемике» (Время. 1861. № 8)1). Подобными свидетельствами авторов «Гражданина» мы, однако, не располагаем. Предпринимавшиеся в 1910-1930-е годы Л. П. Гроссманом [4, XXIII-XXIV] и Б. В. Томашевским [13], затем в 1960-е годы В. В. Виноградовым [3, 209-211] попытки опознать «вкрапления» текстов Достоевского в некоторых выпусках рубрики «Из текущей жизни» (Гражданин. 1873. №№ 23, 28) противоречат гонорарным расчетам Достоевского по соответствующим номерам «Гражданина» (расчеты опубликованы в 1971 году) [14, 171-172]. К положительным решениям проблемы можно отнести опыт атрибуции И. Зохраб некоторых редакторских вставок $[6,162-163]$.

Предложенные в настоящей статье атрибуции ряда редакторских вставок Достоевского базируются на структурно-содержательном и стилистическом анализе текстов «Гражданина» с использованием (в одном случае) данных гонорарной ведомости. Выявленные микротексты Достоевского имеют разную природу, представляя собой либо дополнения содержательного характера («Из текущей жизни» в № 191873 года, «Хивинский поход» в № 24, «Еженедельная хроника» в № 37), либо результат стилистической правки текста («Петербургское обозрение», № 8, 1873 года), либо ремарки «технического» (отсылочного) характера («Московские заметки» в № 20 1873 года, «Девятое января. Память Великой Княгини Елены Павловны...» в № 21874 года, «Иностранные события» в № 41874 года).

Результаты исследования были частично представлены нами в докладах на XXIII Международных Старорусских чтениях «Достоевский и современность» (2008) [10] и III Международном симпозиуме «Русская словесность в мировом культурном контексте» (2009) [11] [12]. 


\section{<Вставка в «ПЕТЕРБУРГСКОЕ ОБОЗРЪНІЕ» \\ В. П. Мещерского> \\ (Гражданинъ. 1873. 19 Февраля. № 8. С. 220)}

Понятіе это - фикція ${ }^{1}$ мы это знаемъ, но въ этой фикціи, мы тоже знаемъ, заключается вся нравственная сила войска: внесите фальшь въ это понятіе, разбейте это начало на разные образы его пониманія, и вся физическая сила войска лишается нравственной силы, которая одна и есть сила, одна и есть непобъдима...

\section{КОММЕНТАРИЙ}

Постоянная рубрика «Петербургское обозрение» открылась в «Гражданине» в ноябре 1872 года. Судя по внутриредакционной переписке, ее основным ведущим был сам издатель В. П. Мещерский ${ }^{2}$. Отдельные сюжеты обозрения могли поручаться иным авторам, - в частности, обозрение для № 52 журнала за 1873 год В. П. Мещерский предлагал дополнить К. П. Победоносцеву ${ }^{3)}$. В ряде выпусков рубрики в 1873 году (№№ 4, 10, 45, 49, 51) несомненно либо вероятно участие Достоевского - соавтора или редактора $[1,168-171 ; 2,16-17,31]$. Есть основания считать, что и обозрение в № 81873 года не избежало правки Достоевского. Основная часть публикации связана с предстоящей реформой армии (1874 года); речь идет о быте столичных воинских частей и взаимоотношениях офицеров. При чтении текста отчетливо бросается в глаза стилистический диссонанс: тяжеловесное казенное многословие, привычное в статьях Мещерского, наскоро сочиненных к очередному номеру, в середине материала прерывается афористически емкой энергичной фразой:

а) «Такимъ образомъ честь мундира, военная честь является уже не чъмъ-то въ родъ высоко-нравственнаго начала, насквозь проникающаго всякаго солдата и чувствуемаго всъми одинаково, а просто предлогомъ сегодня объ этой чести думать одно, завтра другое, сегодня поступать такъ, завтра иначе, и во всякомъ случаъ, относительно пониманія долга военной чести, жить и дъйствовать каждому въ своемъ кружкъ, внъ общенія съ цълымъ корпусомъ офицеровъ, какъ кому заблагоразсудится» (с. 220) (обычный стиль публикаиии);

б) «Понятіе это - фикція, мы это знаемъ, но въ этой фикціи, мы тоже знаемъ, заключается вся нравственная сила войска: внесите фальшь въ это понятіе,

\footnotetext{
${ }^{1}$ Предыдущая фраза «Петербургского обозрения»: «Уже теперь мы слышимъ жалобы на то, что новобранцы въ полкахъ не успьваютъ закаливаться, такъ сказать, въ томъ боевомъ славномъ духъ нашей арміи, который носятъ въ себъ старые солдаты, уходящіе на родину отдыхать; что же будетъ тогда, когда съ кореннымъ измъненіемъ въ формированіи полковъ, свъжій, новый и пришлый элементъ будетъ составлять массу въ каждомъ полку, и не будетъ находить въ корпусъ офицеровъ яснаго и единодушнаго понятія о военной чести?» (Там же).
} 
разбейте это начало на разные образы его пониманія, и вся физическая сила войска лишается нравственной силы, которая одна и есть сила, одна и есть непобъдима...» (диссонанс);

в) «...единомысліе въ пониманіи своего положенія какъ офицера производитъ единомысліе въ пониманіи военнаго долга; а это единомысліе въ пониманіи своихъ прямыхъ обязанностей, столько же служебныхъ, сколько и нравственныхъ, производитъ единомысліе въ пониманіи военной чести. Въ Петербургъ же отсутствіе единомыслія въ пониманіи военнаго долга производитъ слабое участіе нравственныхъ обязанностей въ міръ обязанностей военныхъ; а это слабое участіе нравственныхъ обязанностей имъетъ прямымъ своимъ посльдствіемъ неясное пониманіе военной чести, невысокій ея уровень и отсутствіе единомыслія въ образъ его ${ }^{4}$ пониманія!

Итакъ, установленіе единомыслія во всемъ военномъ міръ Петербурга насчетъ пониманія своихъ обязанностей военныхъ - вотъ средство, и сколько кажется, единственное, для того, чтобы въ томъ же міръ водворить и навсегда упрочить твердое и ясное, для всъхъ одинаковое и для всъхъ обязательное представленіе о военной чести» (с. 221) (вновь ощутим обычный стиль).

Парадоксальное суждение о воинской чести («Понятіе это - фикція <..> но въ этой фикціи <..> заключается вся нравственная сила войска») отсылает постоянного читателя «Гражданина» к недавно помещенному Достоевским в журнале (в № 6 от 5 февраля 1873 года) рассказу «Бобок». В финале рассказа барон Клиневич и инженер, пререкаясь с генералом Первоедовым, свысока трактуют офицерскую честь (ее символом выступает шпага) как понятие иллюзорное, мнимое:

«- Я служил государю моему... я имею шпагу...

- Шпагой вашей мышей колоть, и к тому же вы ее никогда не вынимали.

- Всё равно-с; я составлял часть целого.

- Мало ли какие есть части целого.

- Браво, Клиневич, браво, ха-ха-ха!

- Я не понимаю, что такое шпага, - провозгласил инженер. <...>

- Шпага, сударь, есть честь! - крикнул было генерал» (Д30, т. 21, с. 53).

Еще более органично всему мироощущению Достоевского представление «нравственная сила <..> одна и есть сила». В романном творчестве писателя наиболее показательным примером тому служит диалог князя Мышкина и Коли Иволгина в «Идиоте»:

«- Вот видите, вы говорите, людей нет честных и сильных и что все только ростовщики; вот и явились сильные люди, ваша мать и Варя. Разве помогать здесь и при таких обстоятельствах не признак нравственной силы?

— <..> Гм! Так вы это называете силой? Я это замечу» (Д30, т. 8, с. 113). 
К приметам стиля Достоевского во вставном фрагменте обозрения можно отнести выразительные лексические повторы «мы это знаемъ <..> мы тоже знаемъ», «вся физическая сила войска лишается нравственной силы», «одна и есть сила, одна и есть непобъдима».

\section{<Вставка в ХРоникУ «УЖАСНЫЯ ПРЕСТУПЯЕНІЯ»> (Гражданинъ. 1873. 7 Мая. № 19. С. 577)}

Къ этой льтописи ужасныхъ преступленій присоединяемъ два знаменательные факта, нами взятые изъ «Волжско-Камской Газеты» ${ }^{2}$. На Волгъ, между городами Самарой и Саратовымъ, сорвавшійся плотъ съ четырьмя крестьянами несся затертый льдинами впродолженіи трехъ сутокъ. Во всъхъ селахъ гдъ проходилъ этотъ плотъ, никто изъ жителей не пришелъ несчастнымъ на помощь, не смотря на отчаянные ихъ крики, и на множество людей видъвшихъ плотъ; и они неминуемо погибли бы, еслибы, на четвертый день, не нашелся одинъ купецъ, который вмъсть съ полицейскимъ офицеромъ и рабочими спасъ несчастныхъ крестьянъ.

Воля ваша, а фактъ этотъ новъ въ анналахъ русской народной жизни. Но вотъ фактъ еще новъе. Въ Нижнемъ-Новгородъ нъсколько русскихъ людей зазвали въ кабакъ 11-ти-льтняго мальчика, начали его поить водкою, смъялись надъ нимъ когда онъ началъ пьянъть, а когда напоили его мертвецки, и мальчикъ упалъ въ безчувственномъ состояніи, вышвырнули его на улицу.

\section{КОММЕНТАРИЙ}

23 апреля 1873 года в «Гражданине» (№ 17) открылась постоянная рубрика «Из текущей жизни» - новостная хроника, выходившая без авторской подписи. В июле у рубрики появился постоянный ведущий - А. У. Порецкий. Атрибутировать начальные выпуски «Из текущей жизни» (апрель-май, №№ 17-20 1873 года) в отсутствие гонорарной ведомости журнала за этот период с точностью невозможно; две июньских хроники были составлены В. П. Мещерским (в № 23 от 4 июня ${ }^{5)}$ ) и Ф. М. Достоевским (в № 24 от 11 июня).

Криминальное обозрение «Ужасные преступления» помещено как раздел в выпуске «Из текущей жизни» в № 191873 года. Обзор состоит из четырех блоков информации - заметок без названий. Общей теме, вынесенной в заголовок публикации, соответствуют только три первых заметки: в них описаны случаи отцеубийства, серийного отравления, попытка матереубийства. Короткое четвертое сообщение, составленное по материалам «Камско-Волжской газеты» и заключающее в себе два некриминальных сюжета, прибавлялось к тексту позже («Къ этой лътописи ужасныхъ преступленій присоединяемъ два знаменательные факта...»). Маловероятно, что дополнение к уголовной хрони-

\footnotetext{
${ }^{2}$ Опечатка. Должно быть: «Камско-Волжской Газеты».
} 
ке, не соответствующее ее общему замыслу, принадлежит основному автору публикации; скорее всего, оно было сделано редактором. Работая в «Гражданине», Достоевский ежедневно просматривал множество петербургских и провинциальных газет. «Газеты были его стимуломъ такъ сказать страстно по фактамъ изучать, изсльдовать, разбирать до тонкости эпоху. Онъ принадлежаль къ числу умпвишхъ читать газеты <..> всегда ловилъ характерное», - вспоминал позже о писателе В. П. Мещерскийб). Сюжеты последней заметки «Ужасных преступлений» и лаконичный авторский комментарий, указывающий на значение приведенных фактов («фактъ этотъ новъ въ анналахъ русской народной жизни»), соотносятся с известным издательским проектом героини Достоевского Лизаветы Тушиной («Бесы»), желавшей перепечатывать статьи из газет в особых ежегодных сборниках: «Можно <..> ограничиться лишь выбором происшествий, более или менее выражающих нравственную личную жизнь народа, личность русского народа в данный момент» (Д30, т. 10, с. 104) (этот проект неоднократно ставился в связь с «Дневником Писателя» Достоевского как его прообраз $[7,372 ; 15,122])$. Налицо и параллель с итоговым размышлением очерка Достоевского «Влас» в «Гражданине»: «Но заглядывать в душу современного Власа иногда дело не лишнее. Современный Влас быстро изменяется < .. > Рассказывают и печатают ужасы: пьянство, разбой, пьяные дети <...> цинизм» (Д30, т. 21, с. 41).

Приведенные доводы дают основание предположительно атрибутировать финальную заметку хроники Достоевскому.

\section{<Вставка в «МОСКОВСКІЯ ЗАМъТКИ» И. Ю. Некрасова> (Гражданинъ. 1873. 14 Мая. № 20. С. 587)}

Читатели въ обстоятельномъ описаніи, перепечатанномъ ниже изъ «Моск. ВБд.», ознакомятся съ разными подробностями прібзда шаха, проъзда его по Москвъ, посьщенія имъ Большаго театра и т. д.

\section{КОММЕНТАРИЙ}

Вставка представляет собой редакторскую отсылку к обозрению «Из текущей жизни», где под заголовком «Пріъздъ Персидскаго Шаха въ Россію и пребываніе его въ Москвъ» были помещены перепечатки трех статей «Московских Ведомостей» о визите шаха Наср-эд-дина в Москву 7-9 мая 1873 года (см.: Гражданин. 1873. 14 мая. № 20. С. 597-600).

Шах Персии Наср-эд-дин (1831-1896; годы правления 1848-1896) прибыл в Россию 3 мая 1873 года. В обозрении И. Ю. Некрасова ${ }^{7)}$ «Московские заметки» в № 20 от 14 мая 1873 года визиту шаха посвящен начальный абзац. «Московские заметки» для № 20 писались, по свидетельству самого И. Ю. Некрасова, 8 мая $^{8)}$, т. е. до завершения пребывания шаха в Москве и до выхода в свет второй и третьей из перепечатанных «Гражданином» статей «Московских Ведомостей» о шахе (они посвящены событиям 8 и 9 мая). 


\section{<Примечание к статье В. Ф. Пуцыковича «ХИВИНСКІЙ ПОХОДЪ» \\ (Гражданинъ. 1873. 11 Іюня. № 24. С. 676)}

На это письмо въ «Journal de Génève» ${ }^{3}$ напечатанъ отвътъ генерала Игнатьева ${ }^{4}$. Генералъ Игнатьевъ пишетъ, между прочимъ, что дъло, задуманное Лессепсомъ ${ }^{5}$, должно оказать громадныя услуги всему человъчеству. «Когда проникнетъ свътъ въ азіатскія страны, говоритъ генералъ Игнатьевъ, всъ должны будутъ убъдиться въ неосновательности тъхъ обвиненій, которыя взводятся на Россію, и всъ убъдятся въ благотворности нашего вліянія, оказываемаго тамъ водвореніемъ мира и распространеніемъ цивилизаціи». Въ заключеніе г. Игнатьевъ говоритъ, что, по его мнънію, съ нимъ согласится наше правительство и высказываетъ надежду на то, что и въ Англіи государственные люди сознаютъ, что это предпріятіе принесетъ болъе пользы самой Англіи, чъмъ Россіи.

\section{КОММЕНТАРИЙ}

Примечание относится к следующей фразе статьи «Хивинский поход» (раздел «Два слова объ англійской печати и отношеніи ея къ общечеловъческому дълу»): «Недавно знаменитый Лессепсъ, творецъ баснословнаго суэцкаго канала, обратился съ письмомъ къ нашему послу въ Константинополь, генералу Игнатьеву, въ коемъ предложилъ слъдующій проектъ: провести желъзную дорогу изъ нашего Оренбурга черезъ среднюю Азію въ Калькутту и сдълать, такимъ образомъ, возможнымъ переъздъ изъ Лондона въ Индію въ одну недълю».

В мемуарной статье «Предсказания Ф. М. Достоевского о конституции и революции в России» В. Ф. Пуцыкович вспоминал об активном вмешательстве Достоевского в тексты, подготовленные им для «Гражданина»: «...Достоевскій, съ которымъ, почти вмъстъ, неръдко приходилось мнъ составлять статьи» (Берлинскій Листокъ. 1906. 25 января. С. 6). Факт редакторского участия Достоевского в серии компилятивных статей В. Ф. Пуцыковича «Хивинский поход» (Гражданин. 1873. №o $23-26,28,29)$ был установлен В. А. Викторовичем, определившим, что Достоевским подобраны газетные материалы к обзору «Хивинский поход» для № 26 «Гражданина» $[8,388]^{9)}$.

3 «Journal de Genève» - швейцарская франкоязычная общественно-политическая и литературная газета, выходящая с 1826 года. Опечатка в названии издания допущена в «Гражданине».

${ }^{4}$ Игнатьев Николай Павлович, граф (1832-1908) - русский дипломат и государственный деятель, посол в Турции в 1864-1877 годах.

${ }^{5}$ Лессепс (Lesseps) Фердинанд-Мари, виконт де (1805-1894) - французский предприниматель, дипломат, организатор строительства Суэцкого канала (1859-1869). 
Сверка гонорарных расчетов по № 24 «Гражданина» показывает, что статья «Хивинский поход» в этом номере принадлежит Пуцыковичу не полностью. За две статьи - компиляцию «Хивинский поход» и оригинальный материал «Проект адвокатской реформы» - Пуцыковичу было начислено 18 р. 76 к. [5, 305]. Оригинальные проблемные статьи в «Гражданине» оплачивались по норме 5 копеек за строку; объем статьи «Проект адвокатской реформы» - 220 строк, за нее полагалась выплата 11 рублей. Объем обозрения «Хивинский поход» в № 24 равен 208 строкам, оплачивался материал по 4 копейки за строку ${ }^{10)}-$ итого 8 р. 32 к. Сумма гонорара Пуцыковича за № 24 должна была составить 19 р. 32 к., т. е. на 56 к. больше реальной выплаты. Не были оплачены 14 строк по 4 копейки. Объем сноски-примечания «На это письмо въ “Journal de Génève” <...> самой Англіи, чъмъ Россіи» в «Хивинском походе» составляет «искомые» 14 строк.

Есть признаки того, что сноска-примечание добавлялась к уже готовому материалу. В примечании кратко пересказывается ответ русского посла в Турции Н.П.Игнатьева на письмо французского предпринимателя Ф.-М. де Лессепса. В основном тексте «Хивинского похода» упоминается лишь письмо Лессепса и нет сведений об ответе Н. П. Игнатьева. По-видимому, на момент написания «Хивинского похода» его автор не знал об ответном письме.

Сноска-примечание, целиком построенная на пересказе публикации «Journal de Genève», с ее дословным цитированием, выбивается из общей структуры текста последнего раздела статьи «Хивинский поход» - «Два слова об английской печати и отношении ее к общечеловеческому делу». Раздел (два абзаца) представляет собой отклик на материалы зарубежной, главным образом английской, печати о хивинском походе и о русско-британских отношениях. В основном тексте раздела зарубежные издания — «Times», «Morning Post», «Daily News», «Daily Telegraph» - упоминаются без сколько-нибудь конкретных ссылок и цитат. Этому есть объяснение: в списке «иностранных повременных изданий», которые редакции «Гражданина» было разрешено получать в 1873 году без цензуры, из названных газет значится только «Тіmes» (см.: РГИА. Ф. 776. Оп. 11. 1872 г. Д. 134. Л. 38). В. Ф. Пуцыкович при подготовке статьи поневоле должен был обращаться ко вторичным источникам информации. Цитированный в сноске-примечании «Journal de Genève» в списке разрешенных изданий есть.

Примечание к «Хивинскому походу» Пуцыковича составлено, несомненно, Достоевским, т. к. издателя и фактического соредактора «Гражданина» В. П. Мещерского в июне 1873 года не было в С.-Петербурге. 


\section{<Вставка в пубдикацию «ЕЖЕНЕДЪДЬНАЯ ХРОНИКА»> (Гражданинъ. 1873. 10 Сентября. № 37. С. 988)}

Въ Старой Руссъ, 30 августа, открыты женская прогимназія и ремесленное училище.

\section{КОММЕНТАРИЙ}

Рубрика «Еженедельная хроника» открылась в «Гражданине» 10 сентября 1873 года (с № 37). Сохранились гонорарные расчеты всего по трем номерам журнала (№№ 37, 38 и 391873 года) с «Еженедельной хроникой». Гонорар за «хронику» в № 37, очевидно, никому не начислялся; выпуски рубрики в №№ 38 и 39 оплачены В.Ф. Пуцыковичу. «Еженедельная хроника» «Гражданина» представляла собой краткую сводку новостей внутренней жизни России, составленную отчасти по сообщениям сотрудников редакции, отчасти по публикациям петербургской и провинциальной прессы. «Еженедельная хроника» в № 37 открывается десятью сообщениями без ссылок на печатные источники; этот блок информации имеет характер преимущественно официальной и придворной хроники. Далее следует дайджест из сообщений «С.-Петербургских Ведомостей», «Биржи», «Московских Ведомостей», «Архангельских Губернских Ведомостей». В его составе помещено без ссылки на источник известие об открытии учебных заведений в Старой Руссе.

Данное сообщение мы атрибутируем Ф. М. Достоевскому как единственному сотруднику «Гражданина», регулярно бывавшему в Старой Руссе летом 1873 года.

\section{<Вставка в статью К. П. Победоносцева «ДЕВЯТОЕ ЯНВАРЯ. Память Великой Княгини Едены Павдовны въ Крестовоздвиженской общинъ»> (Гражданинъ. 1874. 14 Января. № 2. С. 40)}

(Ниже помьщается краткій ея очеркъ).

\section{КОММЕНТАРИЙ}

Ремарка относится к следующей фразе статьи К. П. Победоносцева ${ }^{11)}$ : «Дьятельность Крестовоздвиженскихъ сестеръ въ Севастополь и въ Крыму принадлежитъ исторіи». Ремарка представляет собой отсылку, явно редакторскую, к очерку Н. И. Соловьева «Севастопольские подвижницы», напечатанному в том же номере «Гражданина» (с. 49-55). Деловой стиль ремарки Достоевского контрастирует с возвышенным слогом основного текста статьи (ср. следующую за ремаркой фразу: «Она (деятельность Крестовоздвиженских сестер. - А. О.) составляетъ цълую поэму, которая тъмъ драгоцъннъе для насъ что представляетъ непрерывный рядъ дълъ, совершавшихся въ простоть, безъ всякой мысли о подвигъ или заслугъ»). 
Крестовоздвиженские сестры - община сестер милосердия, основанная великой княгиней Еленой Павловной (1805-1873) во время Крымской войны для ухода за ранеными.

\section{<Вставка в статью В. Ф. Пуцыковича «ИНОСТРАННЫЯ СОБЫТІЯ» \\ (Гражданинъ. 1874. 29 Января. № 4. С. 105)}

(о новыхъ узаконеніяхъ, вырабатываемыхъ правительствомъ въ настоящее время см. ниже «Церковныя дъла въ Германіи»)

\section{КОММЕНТАРИЙ}

Данная ремарка (также, по-видимому, редакторская) относится к следующей фразе статьи В.Ф. Пуцыковича: «При содъйствіи либеральнаго большинства парламента, правительство поспьшило издать нъсколько узаконеній, касающихся подчиненія духовной администраціи правительственнымъ властямъ». Статья «Церковные дела в Германии» (с. 106-107; подпись: Z.Z.) была помещена в № 4 «Гражданина» 1874 года вслед за «Иностранными событиями» В. Ф. Пуцыковича. Автором этой статьи был К. П. Победоносцев ${ }^{12)}$.

\section{ПРИМЕЧАНИЯ}

1) Ф. М. Достоевский в воспоминаниях современников: в 2 т. М., 1990. Т. 1. C. 434 .

${ }^{2)}$ См.: РО ИРЛИ. Ф. 100. № 29777. Л. 6, 8, 14 об., 30-31, 79; НИОР РГБ. Ф. 93. II.6.77. Л. 11, 15; Д30, т. 29, кн. 1, с. 305; Литературное наследство. Т. 15. М., 1934. C. 129.

3) См.: Литературное наследство. Т. 15. М., 1934. С. 129.

4) Опечатка. Должно быть: «ее» (чести).

5) Атрибутируем по связи сюжетов хроники с известными выступлениями В.П. Мещерского в «Гражданине» и исходя из структуры текста, типичной для публикаций Мещерского, в частности, в отделе «Ералаш» (Гражданин. 1872. №№ 32, 34; 1873. №№ 2, 3). Кроме того, выпуск «Из текущей жизни» в № 231873 года (судя по гонорарным расчетам Достоевского за этот номер [5, 305]) никому не оплачивался: из авторов регулярных рубрик-обозрений на безгонорарной основе работал в «Гражданине» лишь В. П. Мещерский.

6) Кн. В. М. [Мещерскій В. П.] Воспоминанія о Өедорь Михайловичь Достоевскомъ // Добро. 1881. № 2-3. С. 33.

7) Обозрение подписано псевдонимом Москвичъ, который атрибутируется по эпистолярным источникам: письмам И. Ю. Некрасова к Ф. М. Достоевскому 
1873-1874 годов (РО ИРЛИ. Р. І.ОП. 6. № 139) и письму В. П. Мещерского к Ф. М. Достоевскому от 20-22 августа 1873 года (НИОР РГБ. Ф. 93.II.6.77. Л. 13).

8) Дата указана в тексте: «...въ Москвь вчера съ вечера, посль яснаго утра и полдня, осенній холодъ, а сегодня (8 мая) хмурое небо и почти тотъ же холодъ...» (Гражданин. 1873. № 20. С. 587).

9) Сам текст этого обзора, судя по гонорарным расчетам за № 26, писал В. Ф. Пуцыкович, а не Ф. М. Достоевский. За публикацию в № 26 Пуцыковичу был начислен гонорар 10 р. 40 к. [5, 305]. В обзоре «Хивинский поход» 260 строк (включая заголовок). 260 х 4 к. = 10 р. 40 к. Другие публикации в № 26 1873 года не могут быть атрибутированы Пуцыковичу.

10) Такая норма начисления следует из гонорарных расчетов по №№ 23-26, 28 и 29 «Гражданина» 1873 года. В. П. Мещерский в письме Достоевскому от 1 июля 1873 года предлагал «статьи компилативнья (так! - А. О.) какъ напр<импрь>

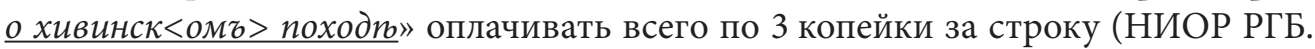
Ф. 93.II.6.77. Л. 7 об.).

11) Подпись под статьей - криптоним $B$. , который атрибутируется К. П. Победоносцеву по эпистолярным источникам (см.: Литературное наследство. Т. 15. С. 124-125, 127-129).

12) Принадлежность криптонима Z.Z. под публикациями «Гражданина» К. П. Победоносцеву подтверждается письмами Победоносцева Достоевскому (см.: Литературное наследство. Т. 15. С. 125-127).

\section{СПИСОК ЛИТЕРАТУРЫ}

1. [Викторович, В. А.] Ф. М. Достоевский. Новоатрибутированные статьи 1872-1874 гг. (Атрибуция и научный комментарий доктора филологических наук В. Викторовича) / В. А. Викторович // Знамя. - 1996. - № 11. - С. 151-177.

2. Викторович, В.А. Достоевский в Обществе любителей духовного просвещения / В. А. Викторович // Достоевский и мировая культура. - 2004. - № 20. - С. 9-39.

3. Виноградов, В.В. Из анонимного фельетонного наследия Достоевского / В. В. Виноградов // Исследования по поэтике и стилистике. - Ленинград : Наука, 1972. - С. 185-211.

4. Гроссманъ, Л. [П.] Предисловіе / Л. П. Гроссман // Ө. М. Достоевскій. Полное собраніе сочиненій : в XXIII т. / Ф.М.Достоевский. - Санктпетербургъ ; Петроградъ : Просвъщеніе, 1911-1918. - Т. XXII. - Петроградъ, 1918. - C. VII-XXX.

5. Записная тетрадь (1872-1875) // Литературное наследство. - Т. 83 : Неизданный Достоевский. Записные книжки и тетради 1860-1881 гг. - Москва : Наука, 1971. С. $289-348$.

6. Зохраб, И. Попытка установления вклада Достоевского в редактирование статей сотрудников газеты-журнала «Гражданин» с учетом цензуры того времени. Постановка проблемы / И.Зохраб // Достоевский и журнализм / под ред. В.Н.Захарова, К. А. Степаняна, Б. Н. Тихомирова. - Санкт-Петербург : Дмитрий Буланин, 2013. (Dostoevsky Monographs ; вып. 4). - C. 143-169. 
7. Кийко, Е. И. Дневник писателя. 1873. І. Вступление <комментарий> / Е. И. Кийко // Достоевский Ф. М. Полное собрание сочинений : в 30 т. / Ф. М. Достоевский. Ленинград : Наука, 1972-1990. - Т. 21. - 1980. - С. 371-375.

8. Летопись жизни и творчества Ф. М.Достоевского : в 3 т. - Санкт-Петербург : Академический проект, 1993-1995. - Т. II. - 1994. - 587 с.

9. Нечаева, В. С. Журнал М. М. и Ф. М. Достоевских «Эпоха». 1864-1865 / В. С. Нечаева. Москва : Наука, 1975. - 304 с.

10. Отливанчик, A. В. Ф. М. Достоевский и $\quad$ В.Ф. Пуцыкович - обозреватели международных событий в «Гражданине» (1873 г. - апрель 1874 г.) / А. В. Отливанчик // Достоевский и современность. Материалы XXIII Международных Старорусских чтений 2008 года. - Ч. І. - Великий Новгород, 2009. - С. 273-283.

11. Отливанчик, А. [В.] Ф. М. Достоевский - редактор авторских текстов в «Гражданине» : несколько фактов в развитие темы / А. В. Отливанчик // III Международный симпозиум «Русская словесность в мировом культурном контексте». Избранные доклады и тезисы. - Москва : Фонд Достоевского, 2012. - С. 206-207.

12. Отливанчик, А. [В.] Ф. М. Достоевский - редактор авторских текстов в еженедельнике «Гражданин» (1873-1874 гг.). Новые разыскания и версии / А. В. Отливанчик // Балтика. - Таллин, Эстония, 2010. - С. 69-77.

13. [Томашевский, Б. В.] Из текущей жизни <комментарий> / Б. В. Томашевский // Полное собрание художественных произведений : в 13 т. / Ф. М. Достоевский. - Москва ; Ленинград : Государственное издательство, 1926-1930. - Т. 13. - 1930. - С. 603-604.

14. Туниманов, В. А. Об анонимном фельетонном наследии Ф. М. Достоевского в годы редактирования «Гражданина» / В. А. Туниманов // Русская литература. - 1981. № 2. - С. 169-174.

15. Фокин, П. Е. К вопросу о генезисе «Дневника писателя» за 1876-1877 гг. (Историколитературный аспект) / П. Е. Фокин // Достоевский. Материалы и исследования. T. 13. - Санкт-Петербург : Наука, 1996. - С. 120-130. 
Alexander V. Otlivanchik

(Minsk, the Republic of Belarus)

AlexOt@yandex.ru

\title{
DOSTOEVSKY'S EDITORIAL INSERTIONS INTO THE ARTICLES PUBLISHED IN “GRAZHDANIN” (1873-1874)
}

\begin{abstract}
The author of this article ascribes to Dostoevsky text boxes in "Peterburgskoe obozrenie" ["St. Petersburg review"] of Vladimir Meshchersky ("Grazhdanin", 1873, no. 8) and in the chronicle "Iz tekushchey zhizni" ["Ongoing life"] (1873, no. 19), "Ezhenedel'naya khronika" ["Weekly chronicle"] (1873, no. 37). In addition, the notes to the article of Victor Putsykovich "Khivinskiy pokhod" ["Khiva campaign"] (1873, no. 24) and the editorial remarks in the publications of Ivan Nekrasov, Konstantin Pobedonostsev, Victor Putsykovich are also attributed to Dostoevsky.
\end{abstract}

Keywords: Fyodor Dostoevsky, Vladimir Meshchersky, Ivan Nekrasov, Konstantin Pobedonostsev, Victor Putsykovich, the weekly journal "Grazhdanin", attribution, editing

\section{References}

1. Viktorovich V. A. F. M. Dostoevskiy. Novoatributirovannye stat'i 1872-1874 gg. (atributsiya i nauchnyy kommentariy V. Viktorovicha) [Fyodor Dostoevsky. Newly Attributed Articles. 1872-1874. (Attribution and Scientific Commentary by V. Viktorovich)]. Znamya, 1996, no. 11, pp. 151-177.

2. Viktorovich V. A. Dostoevskiy v Obshchestve lyubiteley dukhovnogo prosveshcheniya [Dostoevsky in the Society of Adherents to the Enlightenment]. Dostoevskiy i mirovaya kul'tura [Dostoevsky and World Culture], 2004, no. 20, pp. 9-39.

3. Vinogradov V. V. Iz anonimnogo feletonnogo naslediya Dostoevskogo [From Anonymous Feuilleton Heritage of Dostoevsky]. Vinogradov V. V. Issledovaniya po poetike $i$ stilistike [Vinogradov V. V. Researches on Poetics and Stylistics]. Leningrad, 1972, pp. 185-211.

4. Grossman L. P. Predislovie [Preface]. Dostoevskiy F. M. Polnoe sobranie sochineniy : v XXIII t. [F. M. Dostoevsky. The Complete Works in 23 vols]. Saint Petersburg, Petrograd, Prosveshchenie Publ., Petrograd, 1918, vol. 22, pp. VII-XXX.

5. Dostoevskiy F. M. Zapisnaya tetrad' 1872-1875 gg. [A Sketch-book of 1872-1875]. Literaturnoe nasledstvo [Literary Heritage]. Moscow, Nauka Publ., 1971, vol. 83, pp. 289-348.

6. Zokhrab I. Popytka ustanovleniya vklada Dostoevskogo v redaktirovanie statey sotrudnikov gazety-zhurnala «Grazhdanin»s uchetom tsenzury togo vremeni: Postanovka problemy [An Attempt to Define Dostoevsky's Contribution to Editing of the Articles of the Employees of the Periodical "Grazhdanin" Considering the Censorship of Those Days: Problem Statement]. Dostoevskiy i zhurnalizm [Dostoevsky and Journalism]. Saint Petersburg, Dmitriy Bulanin Publ., 2013, pp. 143-169.

7. Kiyko E. I. Dnevnik pisatelya. 1873. I. Vstuplenie <kommentariy> [The Writer's Diary. 1873. 1. Introducation <comments>]. Dostoevskiy F. M. Polnoe sobranie sochineniy: $v 30 t$. [F. M. Dostoevsky. The Complete Works in 30 vols]. Leningrad, Nauka Publ., 1980, vol. 21, pp. 371-375.

8. Letopis'zhizni i tvorchestva F. M. Dostoevskogo : v III $t$. [The Chronicle of Dostoevsky's Life and Works in 3 vols]. Saint Petersburg, Akademicheskiy proekt Publ., 1994, vol. 2. 587 p. 
9. Nechaeva V. S. Zhurnal M. M. i F. M. Dostoevskikh «Epokha». 1864-1865 [The Magazine of Mikhail and Fyodor Dostoevsky "Epokha”. 1864-1865]. Moscow, Nauka Publ., 1975. 304 p.

10. Otlivanchik A. V. F. M. Dostoevskiy i V. F. Putsykovich — obozrevateli mezhdunarodnykh sobytiy v «Grazhdanine» (1873 g. - aprel’ 1874 g.) [F. M. Dostoevsky and V. F. Putsykovich as Reviewers of International Events in "Grazhdanin” (1873 - April 1874)]. Dostoevskiy $i$ sovremennost'. Materialy XXIII Mezhdunarodnykh Starorusskikh chteniy 2008 goda [Dostoevsky and Modern Age: Proceedings of the 23d International Readings in Old Russian Culture, 2008]. Velikiy Novgorod, 2009, part 1, pp. 273-283.

11 Otlivanchik A. V. F. M. Dostoevskiy - redaktor avtorskikh tekstovv «Grazhdanine» : Neskol'ko faktov v razvitie temy [F. M. Dostoevsky as an Editor of Author Texts in "Grazhdanin": Some Facts for Developing the Theme]. III Mezhdunarodnyy simpozium «Russkaya slovesnost' $v$ mirovom kul'turnom kontekste». Izbrannye doklady i tezisy [The Third International Symposium "Russian Literature in the World Cultural Context". Selected Reports and Theses]. Moscow, Fond Dostoevskogo Publ., 2012, pp. 206-207.

12. Otlivanchik A. V. F. M. Dostoevskiy - redaktor avtorskikh tekstov v ezhenedel'nike «Grazhdanin» (1873-1874). Novye razyskaniya i versii [Fyodor Dostoevsky as an Editor of Author Texts in the Weekly "Grazhdanin" (1873-1874). New Searches and Versions]. Baltika. Tallin, E’stonia, 2010, pp. 69-77.

13. Tomashevskiy B. V. Iz tekushchey zhizni <kommentariy $>$ [Based on the Facts of Ongoing Life <comments>]. Dostoevskiy F. M. Polnoe sobranie khudozhestvennykh proizvedeniy : $v$ 13 t. [F. M. Dostoevsky. The Complete Works in 13 vols]. Moscow, Leningrad, State Publishing House, 1930, vol. 13, pp. 603-604.

14. Tunimanov V. A. Ob anonimnom fel'etonnom nasledii F. M. Dostoevskogo v gody redaktirovaniya «Grazhdanina» [About Anonymous Feuilletonistic Heritage of F. M. Dostoevsky During the Years of Editorship of "Grazhdanin” ]. Russkaya literatura, 1981, no. 2, pp. 169-174.

15. Fokin P. E. K voprosu o genezise «Dnevnika pisatelya» za 1876-1877 gg. (Istoriko-literaturnyy aspekt) [More on Genesis of "A Writer's Diary" in 1876-1877 (Historical and Literary Perspective)]. Dostoevskiy. Materialy $i$ issledovaniya [Dostoevsky. Materials and Researches]. Saint Petersburg, Nauka Publ., 1996, vol. 13, pp. 120-130. 